\title{
Community Participation in Festival and Digital Tourism Campaign (Case of North Halmahera District, Indonesia)
}

\author{
Yerik Afrianto Singgalen ${ }^{1 *}$, Gatot Sasongko², Pamerdi Giri Wiloso ${ }^{2}$ \\ ${ }^{1}$ Politeknik Perdamaian Halmahera, North Halmahera, North Maluku, Indonesia \\ ${ }^{2}$ Satya Wacana Christian University, Salatiga, Central Java, Indonesia
}

\begin{abstract}
Galela community participation in the implementation of the Festival Tanjung Bongo (FTB) shows the existence of a partnership pattern in accordance with pentahelix elements. This research uses a qualitative method with a case study approach to describe the level of local community participation in the preparation of Festival activities and various dynamics that occur in realizing these activities. In-depth interviews, observation, and document studies were implemented in order to generate data. The triangulation techniques were implemented as data validation techniques to obtain credible information. The results of this study indicate that the local government becomes a stimulus for community participation in the planning and preparation stage of the Tanjung Bongo Festival event, although the activity was postponed due to the refusal from the National Student League for Democracy Executives related to the readiness of supporting infrastructure. On the other hand, the pentahelix element of government synergy, academic, association, community, and media becomes the very essential factors in organizing the festival. Meanwhile, the level of community participation can be categorized to achieve the level of citizen control in accordance with Arnstein (1969).
\end{abstract}

Keywords: Digital Campaign, North Halmahera, Participation, Pentahelix, Tanjung Bongo Festival.

\section{INTRODUCTION}

Tourism in the precarious era shows fluctuations in tourist demand. Lise and Tol [1] show that demand for tourism products is also influenced by climate change, so the prediction of tourist visits from year to year always shows different results. Sharpley [2] provides an overview of tourist demand for rural tourism in Cyprus, where agro-tourism is one of the preferred destinations to visit. Changes in orientation and interest in tourist visits from urban areas to rural areas indicate a desire to be separated from the busy routine of office work, especially tourists with employment backgrounds in urban areas.

The development of tourism in rural areas cannot be separated from the participation of local communities to encourage economic growth. Nevertheless, the previous study showed the existence of limitations on community participation in tourism development, especially in developing countries [3]. Therefore, to accelerate the growth of the rural tourism sector, optimal local community participation is needed.

In the digital age, humans have a new lifestyle that cannot be separated from electronic devices. Technology becomes a tool that can help most of the human needs and can be used to facilitate the task and work; technology brings human civilization into the digital era [4]. Technological developments also bring about changes in tourism marketing strategies, as well as efforts to increase the quantity and quality of tourism products and services cannot be separated from the digital era [5]. The use of technology in the marketing strategy can improve the quality of products and services offered to the consumers [6]. This shows that digital advertisement becomes effective and efficient strategies in marketing the product.

In the context of tourism, marketing of tourism products through social media becomes an effective strategy to increase tourist visits [7]. A digital advertisement is also used in marketing the hotel so as to be able to face market competition [8]. Competition in the hotel industry environment drives a change of innovation in resource management in order to be able to gain a favorable position in the market, thus digital advertisement becomes an effective strategy to compete for consumers [9]. As a service provider, hospitality determines the quality of service provided by the hotel and it affects expectations of individual values, thus digital advertising is based on market segmentation results [10]. This shows that the digital advertisement has been

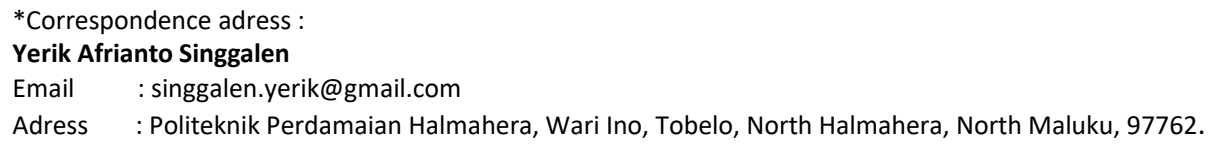


used by the hospitality industry as an integral part of the tourism sector.

Openness in the digital age, providing space for individuals to access information and interact in Internet-based virtual space known as netizen. Each provider of virtual space (provider) implements rules or provides different restrictions according to the typical platform and functionality. In an effort to market tourism destinations, the existence of virtual space and netizens are seen as space and market. It can be an opportunity to promote tourist attraction objects, appeal the tourist to visit and increase tourist traffic. Meanwhile, such an effort can be achieved through a digital advertisement of tourism image in accordance with the preferences of tourists. Nevertheless, in the precarious era, there are consequences that may result in rejection or negative response from the netizens to the marketed products. Thus, the dynamics need to be studied scientifically and profoundly. Based on these considerations, the purpose of this study is to describe the community participation in a festival and digital advertisement case of North Halmahera Regency.

\section{RESEARCH METHODS}

The location of this research is North Halmahera Regency. The method used in this research is qualitative with case study approach at Tanjung Bongo Festival (FTB) in 2017 in Galela Sub-District, North Halmahera District. This study focuses on the participation of multimedia entrepreneurs for the imaging of local tourism destinations through the KASBI Community in the form of digital advertisements supporting the implementation of Tanjung Bongo Festival and the utilization of social media to convey the aspiration of Tanjung Bongo Festival's delay.

\section{Data Collection}

The data collection techniques used is indepth interviews, observation and document studies. In-depth interviews were conducted with Higaro Multimedia entrepreneurs (HS) and Manyawa Multimedia (SRK). The discussion was held with ST and MS related to the implementation of Tanjung Bongo Festival. The document study was conducted using the Regional Tourism Development Master Plan 2011 and Regional Tourism Development Plan and Strategy 2016-2021. Meanwhile, tracing information through social media and search engines are used to provide more information about the analysis in this study. In addition, the data validation technique of triangulation was used to obtain credible information.

The data collection process is done through several approaches. In the early stages, researchers conducted a discussion with multimedia entrepreneurs in Tokuwela coffee shop and Kedai Kopi coffee shop about business related development and tourism in North Halmahera. Through intense communication with multimedia service entrepreneurs, the researcher seeks to identify problems and challenges in developing business as well as multimedia service entrepreneur's participation in North Halmahera's tourism development. Through multimedia service entrepreneurs, researchers are associated with coffee shop entrepreneurs and KASBI community in North Halmahera. This is an opportunity for researchers to examine information in depth related to parties involved in tourism according to pentahelix elements.

Furthermore, the researcher conducted observations at research sites and discussed with local communities who work as a provider of sea transport services to tourist sites. To ensure the accuracy of the information received, researchers clarified by tracing information in social media and news online through the development of tourism in North Halmahera specifically the Tanjung Bongo Festival. The valuable opportunity researchers have gained is the opportunity to discuss with the youth of the National Student League for Democracy Executives with the arguments against the Tanjung Bongo Festival. The debate between netizens that occurred in social media, also makes it easier for researchers to obtain information related to the development of Tanjung Bongo Festival. Thus, the information obtained can support the data analysis in this scientific article.

\section{Data Analysis}

The data analysis was carried out using triangulation, namely a comparative approach to the results of observations, in-depth interviews, and document studies. In order to obtain valid data, the depth of data is required. Therefore the research process takes a long time in order to conduct the interviews, observation, and study of documents. In the context of this research, the process of data collection is done not only in a formal but also by the non-formal way, which means through family or kinship approaches. Thus, researchers try to build good relationships first so that the data obtained is not only from the 
surface but from deeper and more trustworthy sources.

\section{RESULT AND DISCUSSION}

\section{Digital Tourism Campaign in North Halmahera}

The Multimedia and Multigrade Business Entrepreneurs not only make videos or take pictures for personal gain, but they also documented the potential of regional tourism and advertisement in social media for the promotion of tourism destinations in North Halmahera. This shows the existence of communication strategies in the digital age to introduce and promote the resulting product. In the social context of strategy, promotion of products on social media is an integration for the relationship between the company and the consumer can be well established [11]. Social media is an online medium in which its users can easily participate, share and create content including blogs, social networks, wikis, forums, and virtual worlds, even used as a promotional tool because it has a direct connection with its users [12]. Thus, the digital advertisement of tourism image in the precarious era becomes an effective strategy to introduce tourism products in an area to tourists.

Manyawa Multimedia Entrepreneurs has produced a number of works in the form of videos and photos about the existing condition of tourism in North Halmahera in social media promotion. The experience of producing works to promote North Halmahera tourism has started since 2011, as well as expertise in the field of visual communication design is supported by the background of entrepreneurial studies. The profession as a photographer or videographer is run professionally to raise awareness about the value of an artwork. Interpersonal influence and word-of-mouth (WOM) is ranked the most important information source when a consumer is making a purchase decision [13]. These influences are especially important in the hospitality and tourism industry, whose intangible products are difficult to evaluate prior to their consumption. This shows that digital advertisement and promotion play an important role in increasing tourist visits to tourism destinations. As for some of the works of Manyawa Multimedia can be seen in Figure 1.

Figure 1 is some work produced by Manyawa Multimedia entrepreneurs related to digital advertisement of tourism image of North Halmahera. In addition, Higaro Multimedia entrepreneurs also produced a number of works on travel experiences to cultural portraits of local communities as an integral part of the tourism sector. As for, some of the works of Higaro Multimedia can be seen in Figure 2.

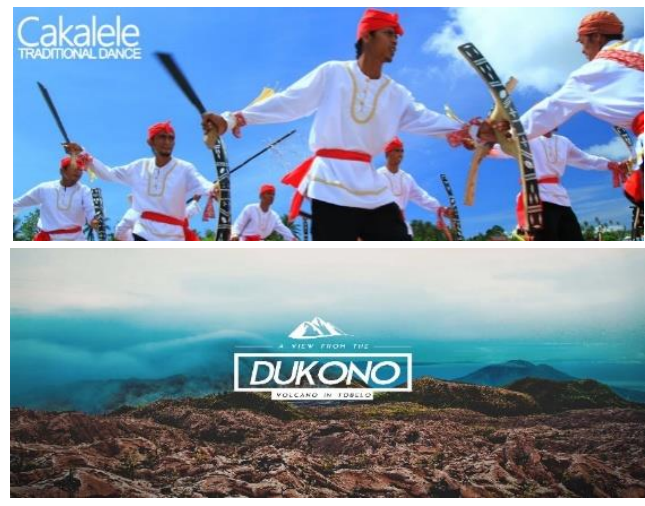

Figure 1. Manyawa Multimedia's Works in North Halmahera Tourism Imagery (Source: Manyawa Multimedia, Stive Recaldo Karimang Facebook Profile, 2018)
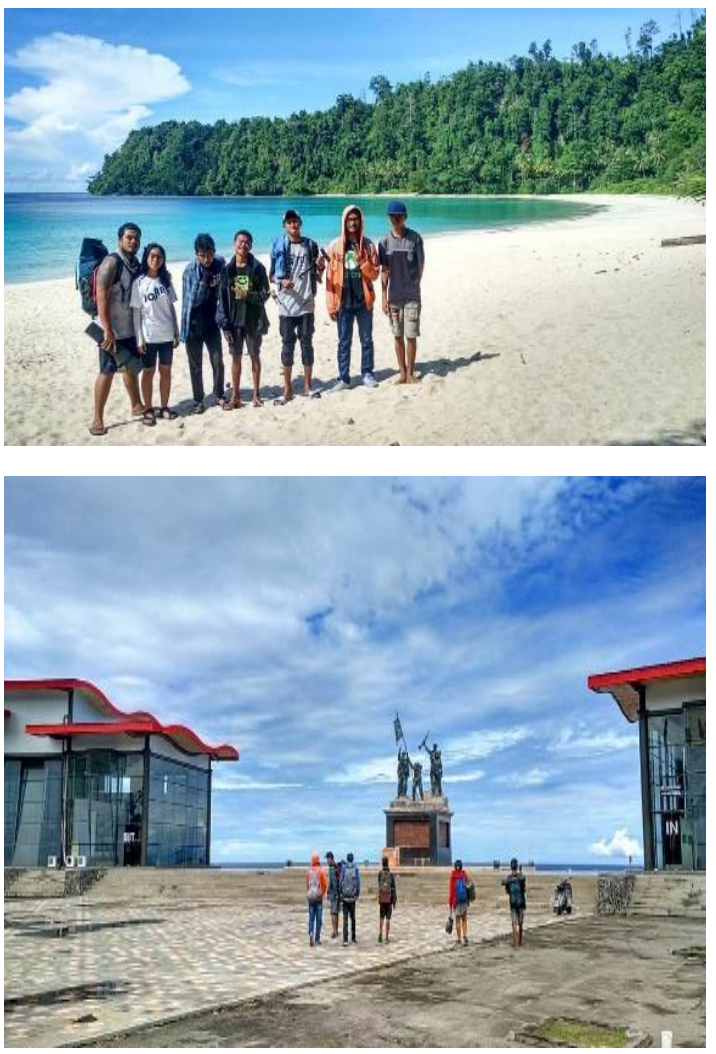

Figure 2. Higaro Multimedia's Works in Regional Tourism Imagery (Source: Higaro Multimedia, Enda Cafarunerz Facebook Profile, 2018)

Figure 2 is documentation of Higaro Multimedia business travel. This shows the existence of a digital campaign to promote tourism through personal experience [14]. Tourism marketing through personal experience documentation form is the most effective imaging 
strategy [15]. This shows that each multimedia entrepreneur has their own way of advertising tourism in North Halmahera.

\section{Raja Ampat Miniature: Doro Somola Beach (Tanjung Bongo)}

Social media plays a significant role both on the demand and on the supply side of tourism [16]; allowing the destinations to interact directly with the pre-visitors via various internet platforms that allow them to monitor and react on visitors opinions and evaluations of advertised services. In Indonesia, especially on North Maluku Province, North Halmahera District, Doro Somola or Tanjung Bongo Tourism Destination began to become a trend in social media since 2016 . It can be seen from the documentation of tourism brand advertised in social media.

On December $6^{\text {th }}, 2016$, blog.reservasi.com published a travel experience to Tanjung Bongo under the title of Small Raja Ampat Replica from North Halmahera. On January $8^{\text {th }}, 2017$, jalamalut.com participated in promoting the natural beauty of Tanjung Bongo by releasing an article titled Doro Somola, Miniature Bair and Raja Ampat in Galela. On the same date, newtampanuli.com also released a news story titled Similar to Raja Ampat, Tourist Flood that shows the natural beauty of Tanjung Bongo. On January $31^{\text {st }}, 2017$, lifestyle.okezone.com released an article titled Miniature Raja Ampat, Apparently in North Halmahera. On February $12^{\text {th }}, 2017, i-$ news TV released the news entitled Tanjung Bongo in Halmahera as Raja Ampat Miniature.

Furthermore, Tanjung Bongo became a trend in social media; it attracts domestic and foreign tourists to visit the location. In addition, tourists visiting Tanjung Bongo also advertised Tanjung Bongo in the form of a private video. This shows the imaging of tourism destinations through technology information as a tourism promotion strategy of North Halmahera.

\section{Partnership in Preparation of Tanjung Bongo Festival}

Cross-border partnership in tourism resource management laying the groundwork for sustainable management of cross-border tourism resources [17]. Partnerships in planning for regional development can bring together stakeholders representing interest at national, regional, and local geographical scales [18]. On July $13^{\text {th }}, 2017$, the Local Government of North Halmahera Regency through the Department of Tourism conducted a digital advertisement of festival organizing in indotimur online media. The information circulated online with news theme North Halmahera government will organize Canga Festival and Wonderful Halmahera Festival that include the statement of Joice Betsy Mahura as Head of Department of Tourism about the planning of the festival. On November $7^{\text {th }}, 2017$, Beritadaerah.com announces different information with the theme of North Halmahera Regency Preparing for Tanjung Bongo Festival (FTB). This indicates a change in the festival plan as published in July.

Festival Tanjung Bongo (FTB) is a cultural festival that will be held on December $7^{\text {th }}-9^{\text {th }}, 2017$ has the purpose of digging and lifting back the values of the local culture. In addition, the FTB is organized as an effort to promote regional tourism (destination branding). The brand becomes a differentiating factor of products or services and has a psychological and symbolic significance for the consumer, so the festival becomes one of the efforts to overcome the crisis of tourist confidence in a region [19]. Nevertheless, the organization of the festival should pay attention to the management capacity associated with the availability of qualified human resources [20]. This indicates that the festival as an effort to promote tourism destinations become an effective strategy in instilling good regional tourism image to tourists.

Although the condition of festival management capacity in terms of human resource availability is also important to consider for the successful implementation of the festival and the achievement of targets or implementation targets festival. In preparation for the festival, the Local Government through the Department of Tourism coordinates with the community to be involved in the festival. Documentation of the coordination meeting of the Tanjung Bongo Festival can be seen in Figure 3.
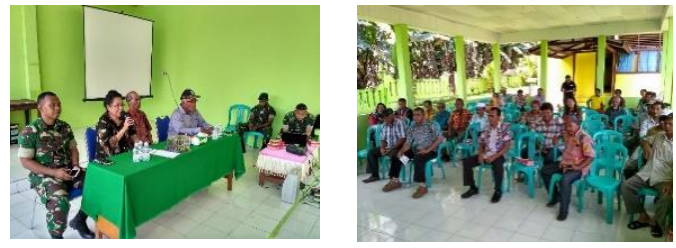

Figure 3. Coordination with Local Communities (Source: Fanpage Festival Tanjung Bongo, 2018)

Figure 3 is a coordination meeting of Tanjung Bongo Festival at Galela District Office on 12 October 2017. In addition, Raisus Banau Force and the local government planned through the Department of Tourism, also provide full support of the implementation of the Festival Tanjung 
Bongo. On November $5^{\text {th }}, 2017$, local communities participated in the construction of supporting tourism facilities and infrastructure by building road access and bathroom facilities for tourists. Meanwhile, the documentation of community participation in preparation for FTB implementation can be seen in Figure 4.
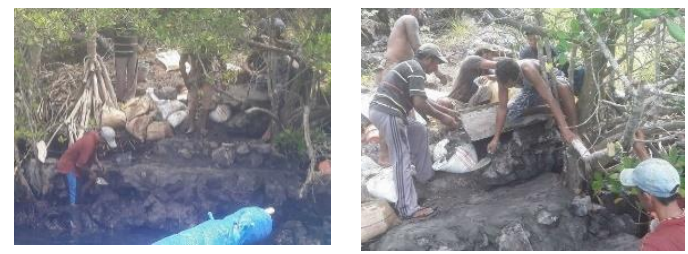

Figure 4. Community Participation in the Preparation of Tanjung Bongo Festival (Source: Fanpage Festival Tanjung Bongo, 2018)

Figure 4 shows the presence of community participation in the preparation of the Tanjung Bongo Festival (FTB). In addition on November $17^{\text {th }}, 2017$, students practiced Tokuwela dance which will be displayed in the FTB. Meanwhile, the documentation of community participation in preparation for the implementation of FTB can be seen in Figure 5.
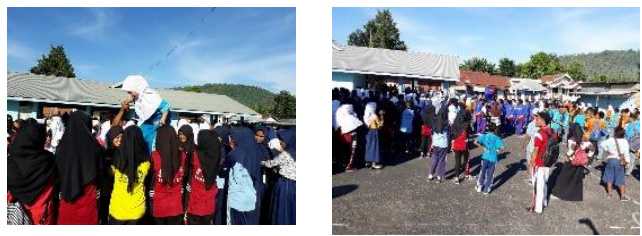

Figure 5. Participation in the Preparation of Tanjung Bongo Festival (Source: Mikdar Ramly Pinoke Facebook Profile, 2018)

Figure 5 shows the participation of students in preparation of the FTB to perform a traditional dance called Tokuwela. The Tokuwela dance is a traditional dance that requires more than 20 dancers, while tokuwela songs accompany the formation of the dancers lining in two rows facing each other while holding hands, then a child will walk on their hands. This dance reflects local cultural values to live with mutual support for one another. The preparation of the festival cannot be separated from the participation of multimedia entrepreneurs to create Tanjung Bongo Festival advertisement. In addition, the preparation of the FTB cannot be separated from the participation of KASBI community and CB community. Meanwhile, one of the forms of participation can be seen from the work of FBT advertising on social media in Figure 6.

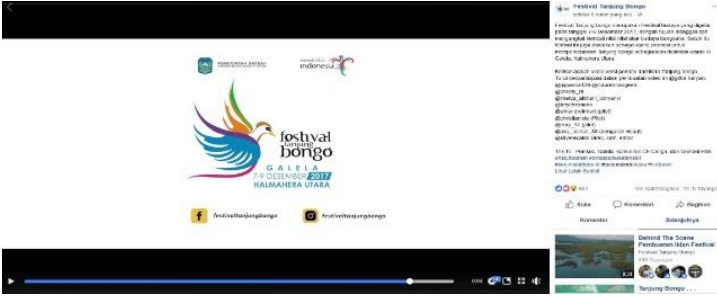

Figure 6. Tanjung Bongo Festival Advertising (Source: Fanpage Festival Tanjung Bongo, 2018)

Figure 6 is an FTB advertising video involving a number of parties (multimedia entrepreneurs, Kasbi community, observers of Halmahera North tourism). This shows the awareness of the community that encourages participation in the preparation of the festival to increase tourist arrivals to North Halmahera. In addition, academic participation in the preparation of FTB can be seen from the willingness of Prof. Thamrin Amal Tomagola as a national figure from Galela, as the presenter at the cultural seminar with the theme of Local Culture Revitalization (Menggali Kembali serta Melestarikan Nilai-Nilai Akar Budaya Bangsa) on November 29 2017. Cooperation between various stakeholders in tourism in preparation of festivals shows the existence of pentahelix government, academia, associations, media, and community), as in figure 7.

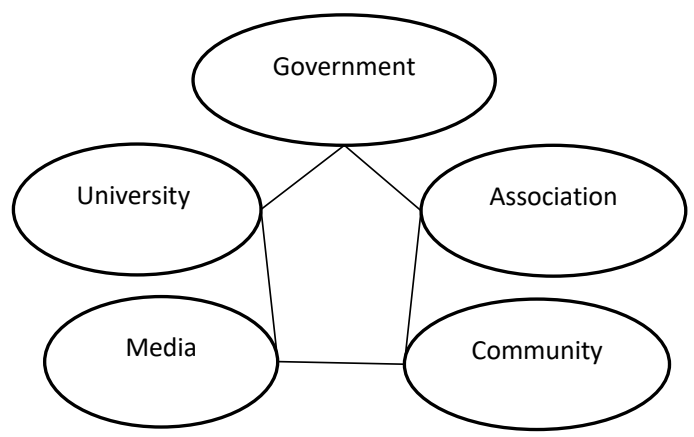

Figure 7. Elements of Pentahelix in Preparation of Tanjung Bongo Festival

Figure 7 shows the existence of partnerships in preparation for the Tanjung Bongo Festival. The Local Government, through the Department of Tourism, coordinates with the Indonesian National Army, KASBI community, CB Community, Academic Organizations and local communities to work together in the implementation of Tanjung Bongo Festival. The partnerships formed can facilitate the process of achieving the goal of festival implementation [21,22]. Partnerships are able to expand access to tourism information potential in remote areas [23]. In addition, 
established partnerships can raise public awareness of the environment in tourism development [24], and enhance ownership of tourism resources [25]. Partnership becomes the most effective strategy in marketing tourism destinations [26]. Thus the benefits of partnership can be seen in the preparation of the FTB to achieve sustainable tourism and communitybased.

\section{Tourism Policy Supervision}

Tourism policy plays a role as important guidance in implementation process [27]. However, destination management organizations need to encourage tourism organizations to design and implement tourism marketing plans with a view in enhancing collaboration and partnerships in a destination [28]. This shows that collaborative advantage in tourism policy implementation and supervision are important. Society as the subject in development, have freedom of expression and oversee the performance of Local Government as executor of public policy. On October $30^{\text {th }}, 2017$, Radar Halmahera print media reported $L M N D$ 's rejection of FTB activities. The National Student League for Democracy (LMND) and Jarod Community in Tobelo rejected the Tanjung Bongo Festival because it was judged to be impartial to people's economy. According to LMND, the budget of IDR $627,830,000$ would be more appropriate if used for infrastructure development in a number of North Halmahera tourism destinations. Meanwhile, the statement of Karlos Dodongko as Executive LMND chairman in Tobelo gave the following statement:

"Tanjung Bongo has never been touched by tourism development and development projects. But, suddenly planning to hold a festival with a budget of IDR600 million for ceremonial events. This is like the rubbish event such as Wonderful Talaga Paca some time ago. We consider this activity to arrive at a reasonable time, so it must be rejected. The local government of North Halmahera and the competent agency (Tourism Department) should evaluate the activities of the new Talaga Paca in 2016."

This statement clarifies that it has not been easy to develop tourism destinations as it demonstrates in Bali. Tourism development must be natural, however, it finds any errors that need wise response [29]. Meanwhile, one of the Jarod Tobelo Community presidents, Stevan Tindage in Radar Halmahera News said that:
"Tanjung Bongo is well known to local tourists without any promotion by the North Halmahera's Department of Tourism. So that the impetus should be done by the Local Government is to build the facility, so that it has value to attract tourists to come to tourism said objects that can sustain Micro, Small, Medium Enterprises and transportation services as well as to increase the income. If the Department of Tourism wants to make Tanjung Bongo Festival as a promotional event, it must be ensured the readiness of infrastructure facilities in Tourism Strategy Area (KSP) Galela and Loloda as already mentioned in North Halmahera Tourism Master Plan known as RIPPDA 2011. Promotion activities are not only presented to local communities and stakeholders of North Halmahera. However, it can provide the impact of national and foreign stakeholder income. Various studies have been conducted to conclude that such activities are not feasible to be implemented this year."

Internal conflicts in tourism development can occur, one of the causes is the struggle for economic opportunities as a result of tourism development [30]. Nonetheless, conflicts can occur due to lack of infrastructure as well as the existence of coercive elements of organizing festivals. On November $3^{\text {rd }}, 2017$, Radar Halmahera published the news under the title Tanjung Bongo Festival Distunite the North Halmahera's Department of Tourism that shows the internal debate of the Department of Tourism related to the implementation of the festival. The news content cites the views of Jhon Anwar Kabalmay as follows:

"The existing construction facilities provided only a toilet, this does not make sense. Then what will be promoted? Which is certainly very embarrassing for the organizing committee because there is no preparation and preparation from the committee itself. So far the implementation of the festival that was made seemed to scattered regional government budget. For example is Wonderful Talaga Paca Festival, after the implementation of the event, there are no tourist visits the site. Even, supporting facilities were destroyed everywhere."

Rejection of the tourism sector is not only related to local wisdom maintaining but concerning regional tourism imaging [31]. On November $5^{\text {th }}, 2017$, the refusal to organize the Tanjung Bongo Festival campaigned in the form of a demonstration in front of North Halmahera 
Regent's Office. Meanwhile, the documentation of the demonstration of FTB's rejection by the Jarod Community and the National Student League for Democracy (LMND Eks) the executive of Tobelo city can be seen in Figure 8.
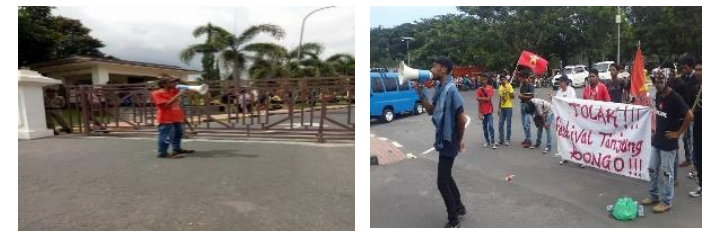

Figure 8. Demonstration of Tanjung Bongo Festival Rejection (Source: Stevan Tindage Facebook Profile, 2018)

Figure 8 shows the presence of public scrutiny of public policy. On November $23^{\text {rd }}, 2017$, a letter of deferment of FTB activities that have not been signed or stamped was leaked on social media. The letter was about the postponement of activities until May, considering the inadequate infrastructure. The circulation of the letter to social media raises a number of debates between the pros and cons of the FTB. This indicates a problem of internal coordination of activity organizers of tourism policy implementers. This indicates that resources, coordination, disposition of implementers and bureaucratic system in the process of implementation of tourism policy must be optimized [27]. Thus, the internal problems of the Local Government Work Units can be solved before they become public issues.

Digital Promotion: Implications of Tanjung Bongo Festival Delay on Regional Tourism Branding

The implications of digital advertisement on social media affect the regional tourism branding specifically the performance of the Department of Tourism [32]. This shows the challenges in building a competitive advantage [19]. Thus it can be seen that digital advertisement not only show the benefits in product marketing strategies or services in the field of tourism but vice versa. In the context of the FTB, on November 24th, 2017, the online media tabloidkontras.com releases news with the title of Towards FTB, a number of Infrastructure Almost Completed by mentioning the statement of Husni Amal as chairman of the local committee of Festival Tanjung Bongo, related enthusiastic attitude of citizens in preparation of FTB implementation as follows:

"Because the field tends to have rocky surroundings, the first thing to do is building access such as a road. In addition to the footpath, the local committee also made some stairs at the boat moorings to Tanjung Bongo hill that tourists often visit to take pictures. About 6 (Six) toilet facilities are provided by the local community through mutual assistance"

This shows the high spirit of the community in participating actively in organizing FTB. Subsequently, on November 25 $5^{\text {th }}$ 2017, Kantorberita.id released news entitled North Halmahera Government suddenly foiled the Festival which showed that the reason for FTB's delay was irrational. On the same date, Kabarmalut.com released the news under the title Local Community Resistance as Festival Procrastination impacts, which is shown with various netizen comrades related to the performance of local government.

Festival is emerging worldwide as a growing and vibrant sector of the tourism and leisure industries and are seen to have significant economic, socio-cultural, and political impacts on the destination area and host groups [33]. However, the level of participation of the local community is important. On $26^{\text {th }}$ November 2017 , kantorberita.id published the news under the title Tanjung Bongo Festival Delay, Mohtar: This Increases the Accumulation of Resistance, by citing Muhtar Adam as an academician of Khariun University in Ternate and shows the performance of the local government that is not optimal. On November $27^{\text {th }}, 2017$, the Executive Committee of Tanjung Bongo Festival went to North Halmahera Regent's Office to request an explanation regarding the festival's postpone-ment. On $28^{\text {th }}$ November 2017, Kabarmalut.com reported the reasons for the cancellation of the festival based on a press conference with the Regent of North Halmahera and the Regional Secretary. Frans Manery as North Halmahera Regent explained that the delay of FTB until May 2018 due to FTB supporting facilities has not been maximal yet, FTB is also not accommodated in the Budget Work Plan (RKA) this year, so it should be allocated in regional government budget on 2018.

Meanwhile, Fredy Tjandua as the Regional Secretary explained, initially North Halmahera Regency Government will hold Canga Festival to Raja Ampat Regency. However, due to various considerations, these activities should be postponed and diverted to FTB activities with the record that all aspects of FTB support have been maximal, especially supporting facilities and infrastructures. The final condition according to survey results in several locations shows that the supporting facilities and infrastructures are not 
optimal yet. Delayed FTB activities that seem impromptu, have implications for local communities. Digital media campaigns related to FTB delays lead to a netizen debate on social media. Meanwhile, the pro and contra symbol of FTB implementation can be seen in Figure 9.
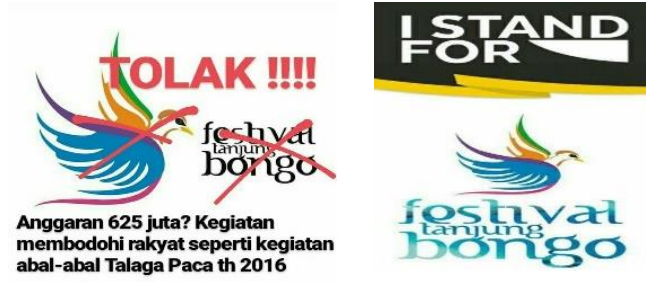

Figure 9. Symbols of Pros and Cons of FTB (Source: Stevan Tindage and Stive Karimang Facebook Profile, 2018)

Figure 9 shows the pros and cons of organizing the FTB on social media. The delay in FTB implementation affects the perceptions of the people who have participated in the preparation of the FTB. Nevertheless, the community strives to keep the FTB organized according to the schedule set. Following a meeting with the local government on $27^{\text {th }}$ November 2017, local committee chairman Husni Amal invited the community to a meeting on $28^{\text {th }}$ November 2017 at Terminal at 20.00 WIT (Eastern Indonesian Time) to discuss the results of the meeting with the local government as well as to discuss the preparation of the FTB implementation.
The result of the meeting culminated in an agreement to continue to hold the FTB on $7^{\text {th }}$ to December $9^{\text {th }}, 2017$. On December $7^{\text {th }}, 2017$, Kabarmalut.com released the news entitled Residents Disappointed with Local Government, then on December $8^{\text {th }}$, suaraindonesia-news. com released the news with the title of Tanjung Bongo Festival Success held from voluntary fund which shows that FTB delays unilaterally make people again uphold the cultural values of bari and lelean (mutual assistance). The form of digital advertisement of a number of online media can be seen in Table 1.

Table 1 represents a number of media promoting the festival management, delays in festivals up to local government up to the success of FTB implementation by local communities. This shows that digital campaigns in addition to providing positive benefits also have the opposite effect. Through the number of online media that preach the development of the implementation of FTB, internal organizational problems can be a public problem because of access to information through electronic or online media. In addition, potential conflicts are vulnerable to provocative media coverage without credible sources of data or information. Therefore, the published news content needs to be carefully reviewed by the reader so as not to lead to unsuccessful understandings that lead to conflict and worsen the image of regional tourism. Therefore, a collaborative management model [34] is required.

Tabel 1. Tanjung Bongo Festival Digital Campaign

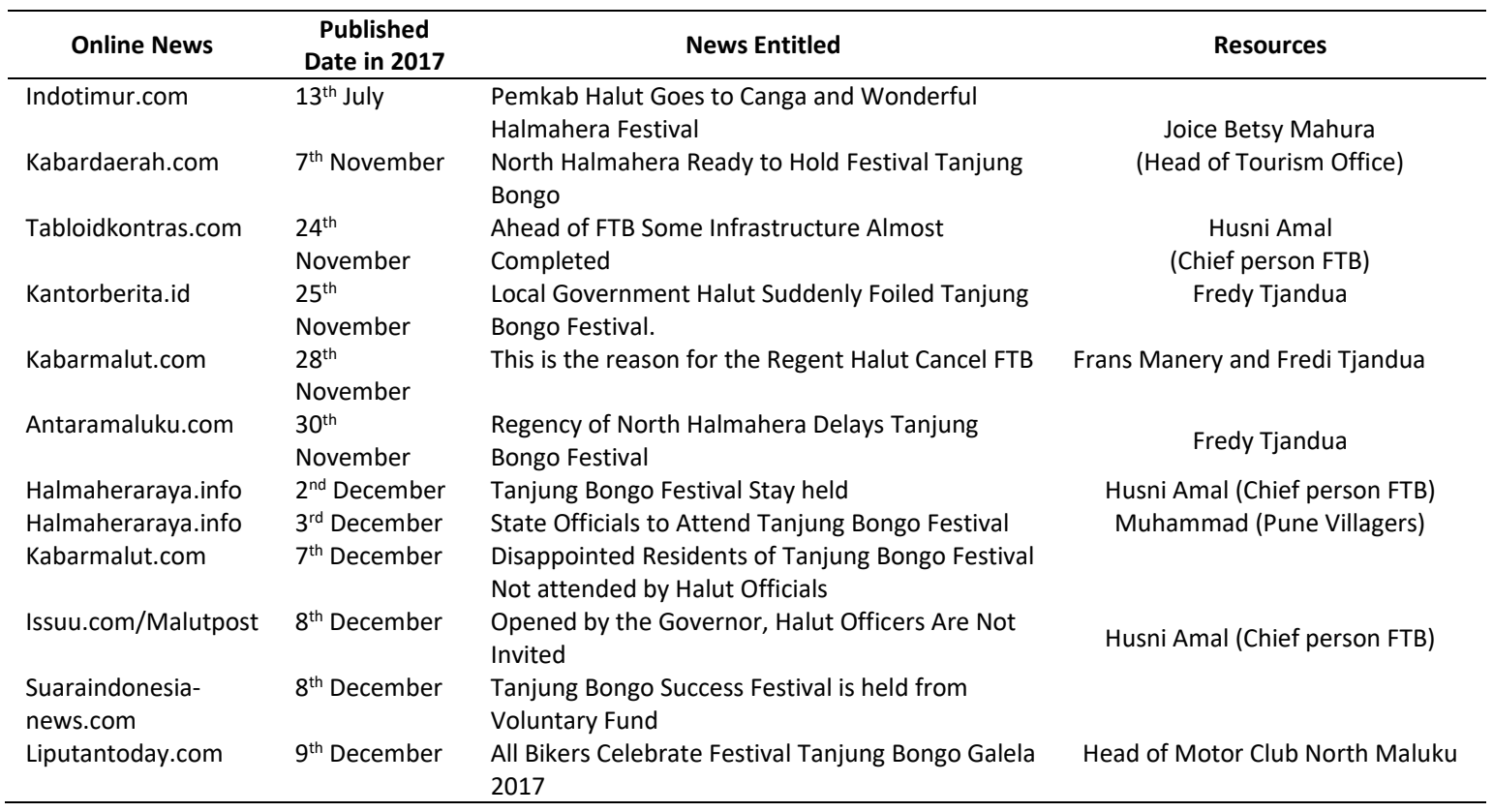


Level of Participation in Tanjung Bongo Festival

The value of local culture known as bari and lelean (mutual assistance) among the Galela community becomes the determining factor of FTB implementation. The existence of cultural values in the implementation of the FTB shows that local expertise can be a patron of tourism development [35]. On the other hand, on December $7^{\text {th }}, 2017$. The opening of the festival is marked by drum band attractions and cultural attractions Tokuwela (Fig 10).

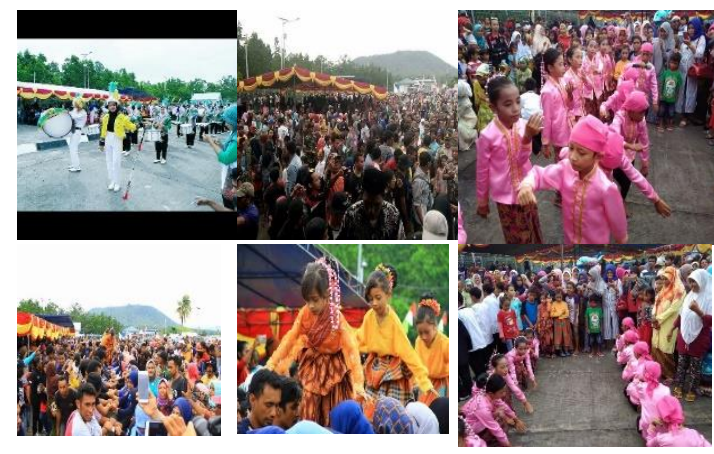

Figure 10. Festival Tanjung Bongo 2017 (Source: Wie Ismail, Yesaya Banari and Jovandry Pangkey Facebook Profile, 2018)

Figure 10 shows the existence of community participation in the implementation of FTB. On December $9^{\text {th }}, 2017$, liputantoday.com released the news with the title All Bikers Celebrate Festival Tanjung Bongo Galela 2017. This shows the support and participation of the community during the implementation of FTB. The level of community participation is stratified according to the gradations of power that can be seen in the process of decision making, implementation and enjoying results until evaluation [36]. The level of participation in question consists of eight levels: influence, therapy, informing, consultation, placation, partnership, delegated power and citizen control.

In the context of community participation in Galela, it can be seen that the level of participation is in the level of citizen control involves the people to plan, implement, evaluate and supervise the activities of Tanjung Bongo Festival and do not depend on the local government. This can be seen from the information published by Suaraindonesianews.com dated December $8^{\text {th }}, 2017$ with the title of news Festival Tanjung Bongo Successful held from voluntary fund that shows the festival held successfully without the help of local government. The sustainable tourism can be achieved by the participation of the community through mutual cooperation, thus the community does not depend on the government in development but become independent in development [37]. Mutual assistance in the context of Galela community is the use of network, trust and cultural values of beri and lelean to achieve development goals. It shows the role of social capital in achieving the success of development [38]. Social capital becomes the center so that challenges in tourism development can be faced together [39]. In addition, the benefits of tourism development can be enjoyed by the community evenly $[40,41]$. Thus it can be seen that the level of community participation in the planning, implementation and evaluation of activities is also determined by social capital to face various challenges in tourism development.

\section{CONCLUSION}

The results of this study indicate that the local government becomes a stimulus for community participation in the planning and preparation stage of the Tanjung Bongo Festival event. Although in the end, the activity should be postponed due to the rejection of the festival by the National League for Democracy (LMND) executives related to the readiness of supporting infrastructure. The rejection of the Tanjung Bongo Festival and the decision of the Regional Government to delay the implementation of the activities have implications for the community's trust or the relationship between the local government and the Galela community. Nevertheless, the community partnership take advantage of local cultural values known as beri and lelean to realize the festival. In the preparation of the festival, it can be seen that there is a partnership pattern according to the pentahelix element that is government synergy, academic, association, community and media in the imaging of regional tourism through FTB activity. Communities have media support and other tourism stakeholders. However, the level of community participation can be categorized as the level of citizen control in accordance with the eight levels of Arnstein because of the community's independence in planning, implementing and evaluating the activities. Thus it can be seen that policies, partnerships and participation are essential factors in the implementation of community-based tourism development in North Halmahera.

\section{REFERENCES}

[1] Lise, W. and R. Tol. 2002. Impact of climate on tourist demand. Climate Change 55(4), 429-449. 
[2] Sharpley, R. 2002. Rural tourism and the challenge of tourism diversification: the case of cyprus. Tourism Management 23(3), 233244.

[3] Tosun, C. 2000. Limits to community participation in the tourism development process in developing countries. Tourism Management 21(6), 613-633.

[4] Setiawan, W. 2017. Era digital dan tantangannya. National Seminar of Education, Hal 1-9.

[5] Chatamallah, M. 2008. Strategi public relations dalam promosi pariwisata: studi kasus dengan pendekatan marketing public relations di Provinsi Banten. MediaTor (Jurnal Komunikasi) 9(2), 393-402.

[6] Sukotjo, H. and R. Sumanto. 2010. Analisa marketing Mix-7P (produk, price, promotion, place, partisipant, process, dan physical evidence) terhadap keputusan pembelian produk Klinik Kecantikan Teta di Surabaya. Jurnal Mitra Ekonomi dan Manjemen Bisnis 1(2), 216-228.

[7] Joehastanti, J. 2012. Strategi pemasaran wisata alam untuk meningkatkan kunjungan wisatawan di kawasan wisata Kabupaten Kediri. Jurnal Revitalisasi 1(2), 61-73.

[8] Purwanto. 2005. Kajian strategi pemasaran hotel dalam menghadapi persaingan. Horeka (Hotel, Restoran and Katering) 10(1), 23-36.

[9] Yoeti, H. 2001. Strategi pemasaran hotel dalam menghadapi persaingan global. Horeka (Hotel, Restoran and Katering) 5(3), 32-43.

[10] Sidik, I. 2003. Orientasi nilai kastemer sebagai dasar menentukan strategi pemasaran Horeka. Horeka (Hotel, Restoran and Katering) 8(3), 199-214.

[11] Piskorski, J. 2013. Networks as covers: Evidence from an online social network. Harvard University, Boston.

[12] Umami, Z. 2015. Social strategy pada media sosial untuk promosi pariwisata Daerah Istimewa Yogyakarta. Jurnal Interaksi 4(2), 195-201.

[13] Litvin, S., R. Goldsmith and B. Pan. 2008. Electronic word-of-mouth in hospitality and tourism management. Tourism Management 29(3), 458-468.

[14] Purwadi, P., A. Novianty, N. Deden and Y. Lestari. 2017. Local tourism promotion through multilingual vlog in Garut, Indonesia. The $5^{\text {th }}$ Asian Academic Society International Conference. Thailand. 1-5.
[15] Kim, D. 2017. Vlog as a branding tool. Metropolia University of Applied Sciences. Helsinki, Finland.

[16] Kiralova, A. and A. Pavliceka. 2015. Development of social media strategies in tourism destination. Procedia-Social and Behavioral Sciences 175(2015), 358-366.

[17] Timothy, D. 2009. Cross-border partnership in tourism management: international parks along The US-Canada border. Journal of Sustainable Tourism 7(3-4), 182-205.

[18] Araujo, L. and B. Bramwell. 2002. Partnership and regional tourism in Brazil. Annals of Tourism Research 29(4), 11381164.

[19] Situmorang, S. 2008. Destination brand: membangun keunggulan bersaing daerah. Wahana Hijau: Jurnal Perencanaan dan Pengembangan Wilayah 4(2), 79-86.

[20] Noho, Y. 2014. Kapasitas pengelolaan desa wisata religius bongo kabupaten gorontalo. Jurnal Nasional Pariwisata 6(1), 8-21.

[21] Darcy, S. and S. Wearing. 2009. Publicprivate partnerships and contested cultural heritage tourism in national parks: A case study of the stakeholder views of the north head quarantine station (Sydney, Australia). Journal of Heritage Tourism 4(3), 181-199.

[22] Hashimoto, A. and D. J. Telfer. 2010. Developing sustainable partnerships in rural tourism: the case of Oita, japan. Journal of Policy Research in Tourism, Leisure and Events 2(2), 165-183.

[23] Schéou, B., and A. Southon. 2013. Ambiguities and difficulties in partnership relations: the case of "fair tourism" in Western Africa. Current Issues in Tourism 16(7-8), 753-772.

[24] Amuquandoh, F. E. 2010. Residents' perceptions of the environmental impacts of tourism in the Lake Bosomtwe Basin, Ghana. Journal of Sustainable Tourism 18(2), 223238.

[25] Lenik, S. 2013. Community engagement and heritage tourism at geneva estate, dominica. Journal of Heritage Tourism 8(1), 9-19.

[26] Middleton, V. T. C. and R. Hawkins. 1998. Sustainable tourism: a marketing perspective. Environment, 287.

[27] Singgalen, Y., P. Wiloso and G. Sasongko. 2017. Evaluation of the implementation of tourism policy. Jurnal Kebijakan and Administrasi Publik 21(1), 82-106. 
[28] Pansiri, J. 2012. Collaboration and partnership in tourism : the experience of Bostwana. Tourism Planning and Development 10(1), 64-84.

[29] Karim, A. 2010. Pariwisata: antara tuntutan industri dan kearifan lokal. KARSA 53(2), 148-158.

[30] Afala, L. 2017. Menalar dinamika konflik wisata Goa Pindul. Journal of Governance 2(1), 19-35.

[31] Buhan, R., A. Wirawan and Sulandjari. 2017. Perlawanan masyarakat Hindu Bali terhadap reklamasi Denpasar 1990-2014. Jurnal Humanis 19(1), 110-115.

[32] Hays, S., S. J. Page and D. Buhalis. 2013. Social media as a destination marketing tool: Its use by national tourism organisations. Current Issues in Tourism 16(3), 211-239.

[33] Arcodia, C. and M. Whitford. 2005. Festival attendance and the development of social capital. Journal of Convention and Event Tourism 8(2), 1-18.

[34] Peranginangin, L. S. U. 2014. Partisipasi masyarakat dalam pengelolaan kawasan konservasi: penganalisa bahan dan pemanfaatan pada Balai KSDA Sumatera Barat. Jurnal Kebijakan and Administrasi Publik 18(1), 68-78.

[35] Jupir, M. M. 2013. Implementasi kebijakan pariwisata berbasis kearifan lokal. Journal of Indonesian Tourism and Development Studies 1(1), 28-38.

[36] Arnstein, S. 1969. A ladder of citizen participation. Journal of the American Planning Association 35(4), 216-224.

[37] Soedibyo, D. and F. H. Habibie. 2005. Bentuk partisipasi masyarakat pada pembangunan daerah wisata. Bintara (Bina Wisata Nusantara) 10(3), 264-275.

[38] Arianto, K., and E. N. Fitriana. 2013. Modal sosial dalam kemandirian masyarakat di bidang kesehatan. Jurnal Kebijakan and Administrasi Publik 17(2), 37-49.

[39] Pamungkas, G. 2013. Ekowisata belum milik bersama: kapasitas jejaring stakeholder dalam pengelolaan ekowisata (studi kasus: Taman Nasional Gunung Gede Pangrango). Jurnal Perencanaan Wilayah dan Kota 24(1), 49-64.

[40] Mardani, A., F. Purwanti, S. Rudiyanti. 2017. Strategi pengembangan ekowisata berbasis masyarakat di Pulau Pahawang Propinsi Lampung. Journal of Maquares 6(1), 1-9.
[41] Yachya, A. N., Wilopo, and M. K. Mawardi. 2016. Pengelolaan kawasan wisata sebagai upaya peningkatan ekonomi masyarakat berbasis CBT (Studi pada kawasan wisata Pantai Clungup Kabupaten Malang). Jurnal Administrasi Bisnis (JAB) 39(2), 107-116. 